\title{
correspondence
}

\section{The Piltdown hoax}

SIR,-Halstead's preliminary presentation of allegedly new material on the Piltdown hoax ${ }^{1}$ could not reasonably be expected to encompass all the evidence which has accumulated in relation to anthropology's most notorious forgery. Nonetheless, one might have hoped that the tape-recorded allegations of the late Professor Douglas would have been accorded a tolerably critical analysis. Such is not the case.

Douglas and Halstead's attempt to implicate Sollas (and Dawson), whilst it may appear plausible to the casual reader, at best represents only a small part of the truth about Piltdown, and at worst depends upon exaggerations and imprecisions. Let me give some examples.

Although Halstead does not qualify Douglas' assertions about Dawson's reputation, they are in fact grossly misleading. Whether or not Dawson was guilty of Piltdown, he certainly did not accuire a reputation for perpetrating hoaxes during his lifetime. In fact he was a respected collector of fossils and antiquities for the British Museum. To be sure, after the exposure of the Piltdown forgery in 1953 , a number of insinuations against Dawson's integrity were assembled, ${ }^{2}$ and it has recently been shown that some Roman brick-stamps which Dawson donated to the British and Lewes Museums are forgeries. ${ }^{3}$ However in the first instance the insinuations may represent retrospective mud-slinging by local Sussex antiquaries jealous of the international fame which Dawson achieved through Piltdown. and in the second instance the possibility remains that Dawson was the dupe rather than the forger. Certainly prior to his death in 1916 . there was not a hint of scandal about Dawson. Even in relation to Piltdown itself, Dawson's guilt is far from proven. Of the three full-length books written about Piltdown after 1953, two argue that Dawson was innocent, ${ }^{4}$ and the third, while implying Dawson's probable guilt, pointedly avoids expressing its final conclusion in positive form."

Apart from glaring inaccuracies such as the above, the Douglas/Halstead hypothesis embodies many statements which are so vague as to be practically worthless as evidence. The potentially crucial assertions that Sollas knew and visited Dawson, that Sollas received a packet of potassium bichromate, and Sollas borrowed some ape's tecth, are left with no firm indications as to when these events allegedly occurred. If they took place after December 1912, their occurrence would almost certainly be irrelevant to the hoax. Even the incident of the Sherborne Horse's Head, which constitutes the most suggestive part of the

Douglas/Halstead case, is open to many interpretations.

Certainly a Sollas/Dawson conspiracy would provide a possible, perhaps even a likely, explanation for the Piltdown hoax, but the best evidence for such a conspiracy lies in areas untrodden by Douglas and Halstead. The 1911 edition of Sollas' Ancient Hunters provides a detailed description of "Heidelberg man", an earlier candidate for the title of "missing link" which probably served as a model for Piltdown, and which is known to have preoccupied Dawson circa 1912. Moreover, since the Piltdown forger chemically treated the cranial fragments in an attempt to make them appear fossilised, ${ }^{6}$ it is surely worth noting that Sollas had done important pioneering work on the chemistry of fossilisation, ${ }^{7}$ work which Dawson may well have utilised in interpreting the Piltdown remains. ${ }^{8}$

However, because of problems surrounding Sollas' motivations, problems which Halstead's communication fails to resolve, I am inclined to lay the blame for Piltdown elsewhere. My current working hypothesis is that Flliot Smith instigated the hoax, and that Smith Woodward may have been a willing accomplice. This hypothesis does much to illuminate a formerly puzzling episode from Australian prehistory, an episode in which, incidentally, Sollas played a supporting role. ${ }^{?}$

IAN LANGHAM

University of Sydney, Australia.

1. Halstead, L. B. Nature 276, 11-13 (1978)

2. Weiner, J. S. The Piltdown Forgery ch. 12 (Oxford University Press, 1955)

3. Peacock, D. P. S. Antiquity 47, 138-140 (1973).

4. Vere, F. The Piltdown Fantasy (Cassell, 1955) Millar, R. The Piltdown Men (Paladin. 1974).

5. Weiner op. cit.. p. 203.

6. Oakley, K. P. Antiquity 50, 12 (1976)

Sollas, W. J. Ann. Mag. Nat. Hist. 20, 285 300 (1877). Sollas, W. J. Rep Brit Assoc $A d v$. Sci. 350 (1879), ibid. 549-50 (1882). 8. Dawson, C. Quart. J. Geol. Soc. Lond. 69,

9. Langham, I. G. The Artefuct (December 1978).

\section{Allies against Lysenko}

SiR,-In Vera Rich's moving account of Professor Lev Tumerman's seven years in solitary confinement (14 December, page 662), she mentions that he recalls "one very good book by Sunnot and Dent". He no doubt meant to refer to the classical textbook of genetics by Sinnott,

E. W. and Dunn, L. C. Principles of Genetics, McGraw-Hill, New York and London, 1925 which went through several editions (the last with Dobzhansky) and which for almost four decádes (19251965) was the standard text in this field. F. W. Sinnott was professor of botany at Columbia and then Yale and L. C. Dunn was professor of zoology at Columbia. Dunn, who died in 1974, was active in the ficld of developmental genetics for more than a half-century; a fascinating review of his life and work has appeared

recently (Bennett, D. Ann. Rev. Genet. 11, 1-12; 1977).

It is interesting that Dunn, who was often bitterly attacked in the United States for his devotion to what were at that time left-wing causes, was an outspoken critic of Lysenko and of the Soviet persecution of their geneticists and of other scientists and intellectuals, such as Tumerman himself.

Department of Biology

J. Gordin Kaplan

University of Ottawa

Ottawa, Canada

\section{Who assesses risk?}

SIR,-I was much struck with Wendy Barnaby's report of the Swedish seminar on risk assessment (7 December, page 554). The impression conveved was that informed and impartial politicians ought to regard a democratic society's evaluation of risk perception as even more important than quantified objective risk. This is tantamount to saying that it is more important to consider the number of people who would be frightened than the number of people who woula be killed.

The conclusion is that one should favour energy production from fossil fuels which kill far more people, rather than nuclear power which frightens far more people.

I can see why short-sighted politicians might approve this view, assuming that the fears of the public will last at least until the next election. Dead people don' have votes. Frightened people do. But I am surprised that Nature appears to approve the same opinion.

Department of Physics J. H. Fremlin

University of Birmingham, UK

\section{Not by force of ARMS}

SIR,--I welcome the article by Joe Schwartz (23 November, page 310 ), drawing attention to the unsatisfactory job security and carecr prospects of research staff. 'Fechnicians and graduate research assistants, as well as post-docs. are often victims of short term contracts.

May I underline the point that it is the quality and strength of local trade union organisation which determines how effectively these issues can be negotiated with each university, medical school, college or institute. For this reason I was alarmed by the suggestion that ARMS "intends to negotiate with employers". Indeed, I am sure it would delight these employers to be relieved of the embarrassing task of trying to justify their practices to the experienced negotiators of strong trade union organisations. I welcome ARMS to the extent that its existence demonstrates the concern felt by research staff, but I must qualify this by warning that the ARMS could backfire if it diverts staff from the need to work within trade unions.

Finally, I should clarify that I am not a "division organiser" for ASTMS (as reported in your article). I am one of many lay activists within ASTMS who have been tackling these issues, and many others, for some years.

London, UK.
Phil.tP Hounsell 